\title{
Melatonin administration during the dry period stimulates subsequent milk yield and weight gain of offspring in subtropical does kidding in summer
}

\author{
R. Avilés, ${ }^{1}$ J. A. Delgadillo, ${ }^{1}$ J. A. Flores, ${ }^{1}$ G. Duarte, ${ }^{1}$ J. Vielma, ${ }^{1}$ M. J. Flores, ${ }^{2}$ K. Petrovski, ${ }^{3}$ L. A. Zarazaga, ${ }^{4}$ \\ and $\mathrm{H}$. Hernández ${ }^{1,5 *}$ (D) \\ ${ }^{1}$ Centro de Investigación en Reproducción Caprina, Posgrado en Ciencias Agrarias, Universidad Autónoma Agraria Antonio Narro, Torreón 27054, \\ Coahuila, Mexico \\ ${ }^{2}$ Instituto Nacional de Investigaciones Forestales, Agricolas y Pecuarias, Campo Experimental La Laguna, Matamoros 27440, Coahuila, Mexico \\ ${ }^{3}$ Davies Research Centre, School of Animal and Veterinary Sciences, The University of Adelaide, Roseworthy 5371, South Australia, Australia \\ ${ }^{4}$ Departamento de Ciencias Agroforestales, Universidad de Huelva, Palos de la Frontera, 21810, Huelva, Spain \\ ${ }^{5}$ Departamento de Ciencias Básicas, Universidad Autónoma Agraria Antonio Narro, Torreón 27054, Coahuila, Mexico
}

\section{ABSTRACT}

In the present experiment, we tested the hypothesis that in does kidding in summer, melatonin administration during dry period is galactopoietic for the subsequent lactation and results in improved growth of their suckling kids. Twenty-five multiparous pregnant creole does were enrolled into a randomized complete block design during their dry period in the $49 \mathrm{~d}$ prepartum, and under natural long photoperiods around the summer solstice, pregnant does either received 2 subcutaneous ear implants (18 mg) of melatonin (MEL, $\mathrm{n}=10$ ) or served as nonimplanted controls (CONT, $\mathrm{n}=15)$. During the first $14 \mathrm{wk}$ of subsequent lactation (suckling and milking periods), MEL does yielded more milk than CONT does. Throughout subsequent lactation, milk composition was not affected by treatment. In MEL does, peripheral triiodothyronine levels peaked at 2 wk of lactation, remaining higher than in CONT does. The mean daily weight gain was higher in MEL compared with CONT kids and was also higher in males than females, and for males, was positively correlated with milk yield. The current data support our hypothesis that melatonin during the prepartum period is galactopoietic in suckling does.

Key words: lactation, suckling doe, grazing, goat kid

\section{INTRODUCTION}

Seasonal breeding mammals are sensitive to changes in day length. Thus, in small ruminants from temperate and subtropical latitudes, photoperiod is the main

Received April 20, 2019.

Accepted August 21, 2019.

*Corresponding author: hernandezhoracio@outlook.com environmental cue that modulates their annual pattern of reproductive activity (Ortavant et al., 1988; Duarte et al., 2010). However, natural oscillations in the photoperiod or alterations by artificial photoperiod can lead to changes in milk production in ruminants with seasonal or nonseasonal reproduction (Linzell, 1973; Dahl et al., 2000). For example, dairy cows and subtropical does exposed to artificially prolonged photoperiods increased their milk yields (Peters et al., 1981; Flores et al., 2011). In contrast, exposure to artificially shortened photoperiods during the dry period increased their milk yields in the subsequent lactation (Auchtung et al., 2005; Mabjeesh et al., 2007). In the 12 wk of subsequent lactation, greater milk yields have been reported for does that received artificial short days during the dry period than those that received long days (Mabjeesh et al., 2007). Furthermore, the circulating plasma triiodothyronine (T3) concentrations were similar in both groups during the dry period, but were greater during lactation in goats exposed to artificial short days. These changes in T3 plasma concentrations partially explain the higher metabolic state during lactation in those does. In fact, in this species, the main effects of T3 are to increase the basal metabolic rate, to make more glucose available to cells, to stimulate protein synthesis, and to increase lipid metabolism (Todini et al., 2007), and therefore it is important as a component in the hormonal galactopoietic complex (Cowie et al., 1964).

One possible explanation by which exposure to shorter photoperiods during the dry period stimulates the subsequent lactation is the extended period of melatonin secretion by the pineal gland. Indeed, submitting female goats to artificial short photoperiods induces an increased duration of melatonin secretion (Deveson et al., 1990) and longer melatonin exposure significantly reduces plasma levels of prolactin $(\mathbf{P R L}$; Auldist et al., 2007). Reduced PRL levels have been reported to promotes involution of mammary glands 
in dairy cows through an increase in the permeability of epithelial cell tight junctions, allowing paracellular transport between the interstitial space and milk (Ollier et al., 2013), and in addition, by augmenting mammary development during pregnancy (Wall et al., 2005). However, it was previously reported in dairy cows that administration of oral melatonin in their dry period did not affect involution of mammary gland (Ponchon et al., 2017). Similarly, in dairy cows administration of melatonin implants during the dry period did not stimulate the subsequent lactation as did short photoperiod (Garcia-Ispierto et al., 2013; Lacasse et al., 2014). To our knowledge, to estimate effects of melatonin administration on the subsequent lactation using melatonin implants, no studies have been conducted in nursing animals. Furthermore, the majority of previous studies have been carried out in animals specialized for milk production receiving adequate nutrition. Nursing does with increased milk production had faster growing kids (Garcia y González et al., 2017). Hence, if administration of melatonin during the dry period could affect the level of milk production, the mean daily weight gain of their offspring should be improved. In this study, we assessed the effect of implantation of exogenous melatonin (to simulate a short photoperiod) during their dry period, on subsequent milk yields and growth of their kids.

\section{MATERIALS AND METHODS}

This study was conducted in accordance with the Official Mexican Norm NOM-062-ZOO-1999 for technical specifications for the production, care, and use of laboratory animals (SAGARPA, 2001).

\section{Location of the Study}

The work was conducted in the Comarca Lagunera region, a subtropical area located in northern Mexico. In this semi-arid region, the caprine population in 2014 was estimated as 413,000 (SIAP, 2014). The natural photoperiod in this region ranges from $10 \mathrm{~h}, 19 \mathrm{~min}$ at the winter solstice to $13 \mathrm{~h}, 41 \mathrm{~min}$ at the summer solstice. The study was carried out from July to midDecember (when the natural photoperiod was from natural long days and decreasing afterward; Figure 1). In these local does, Duarte et al. (2010) determined that exposing the animals to artificial photoperiods of 14 and $10 \mathrm{~h}$ of light per day was interpreted as long and short days, respectively.

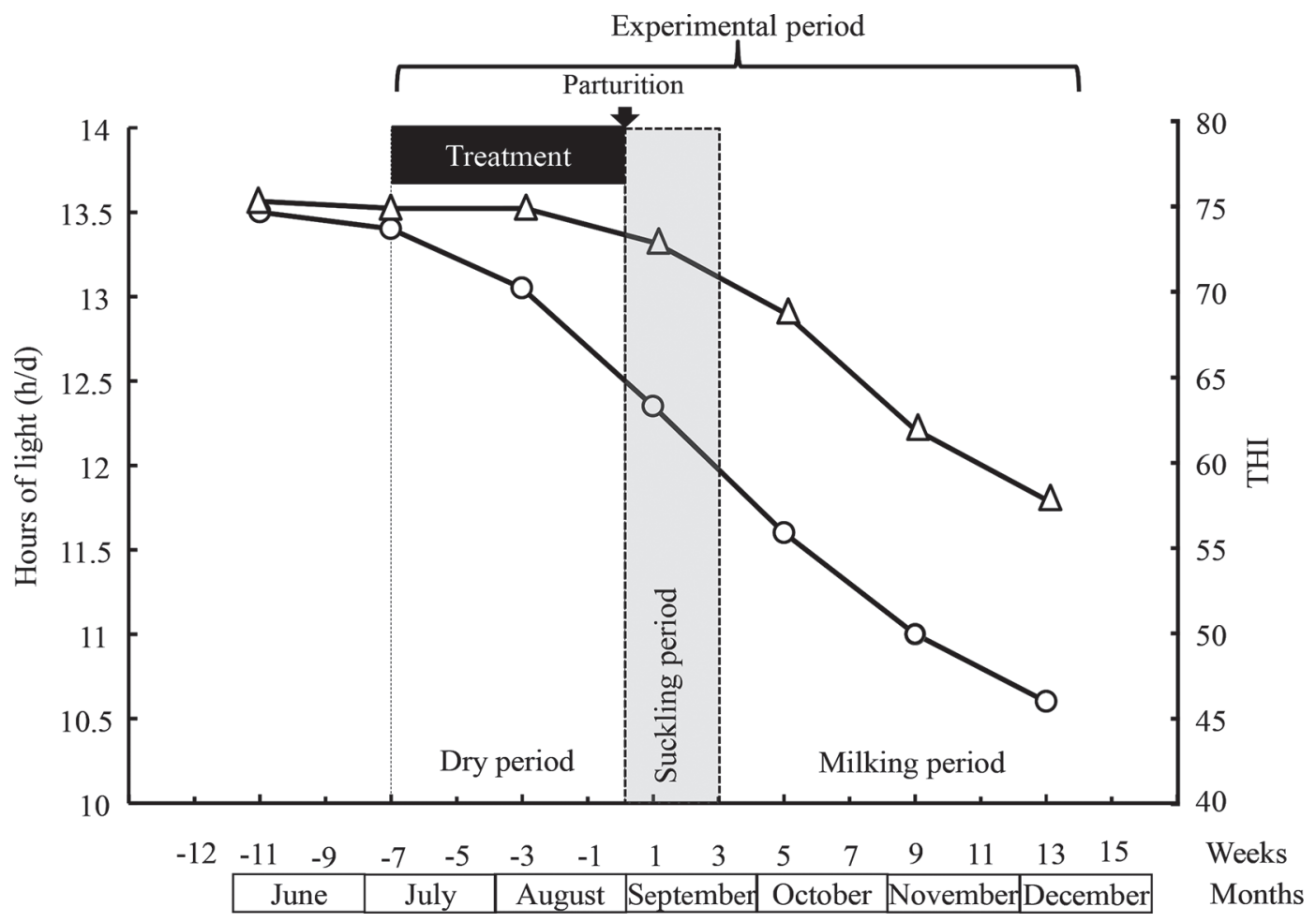

Figure 1. Experimental design showing the natural long days $(\bigcirc)$ and the temperature-humidity index $($ THI; $\Delta)$ prevailing during the summer solstice to which does were subjected. During the dry period, does from the control group received natural long days, and the second group was managed under the same conditions, but each doe was treated with 2 subcutaneous ear melatonin implants (18 mg of melatonin; black bar). Sucking period is indicated by the gray area followed by the hand milking period. 


\section{General Conditions and Treatments}

During pregnancy, 25 creole does were maintained under extensive grazing conditions utilizing uncultivated pastures. After parturition, in addition to grazing, each doe was supplemented in the morning with 0.3 $\mathrm{kg}$ of commercial concentrate containing $18 \%$ of CP (Generaleche, Purina, Irapuato, Mexico). A schematic representation of the experimental design used for this study is shown in Figure 1. At the start of dry period (49 d prepartum), does were blocked into 2 experimental groups based on BCS and the previous lactation milk yield.

Twenty-five pregnant does in their dry period were kept under naturally long days prevailing during the month of July, and remained under natural photoperiod to the end of the study in mid-December. From this group, 15 does were used as a control group (CONT). The remaining 10 does received 2 subcutaneous ear melatonin implants (18 $\mathrm{mg}$ of melatonin, Melovine, CEVA Sante Animale, Libourne, France) and were included in the melatonin group (MEL). In does, these implants release melatonin for about $10 \mathrm{wk}$ and raise daytime concentrations to about $100 \mathrm{pg} / \mathrm{mL}$ (Delgadillo et al., 2001). Implants were removed by means of a simple surgery immediately following parturition.

The first and last goat gave birth on August 23 and September 4 , respectively, and the mean $( \pm$ SEM) date of parturition for all does was August 31 ( $\pm 1.0 \mathrm{~d}$ ). The kids remained with their respective dam during the first $21 \mathrm{~d}$ postpartum and suckled freely from the afternoon (when their dams return from grazing) until the following morning.

\section{Estimation of Milk Yield During the Suckling Period}

The milk yield during the suckling period was estimated using the suckle-weigh-suckle method (Ricordeau et al., 1960). Thus, 2 controlled suckling bouts were performed $12 \mathrm{~h}$ apart after emptying the udder of milk accumulated the previous day. To obtain the total milk yield for a 24 -h period, at the termination of each controlled suckling, 2 IU of oxytocin (Oxilac-Proquivet, Guadalajara, Mexico) was injected into the jugular vein and does were hand-milked to harvest the residual milk; the weight of the residual milk was added to the corresponding difference in the BW of the kids.

\section{Estimation of Milk Yield During the Milking Period}

Once the kids were weaned, milk yield during milking period was assessed each week up to 3.5 mo of lactation by harvesting the milk by hand milking once daily $(0600 \mathrm{~h})$. After hand-milking, 2 IU of exogenous oxytocin was injected into the jugular vein to extract any residual milk. The weight of this residual milk was added to that of the corresponding hand-milking.

The difference in milk collected between CONT and MEL does was calculated by computing the difference of average daily milk yield per doe between the 2 groups for each week, multiplied by 7 , and all were added to obtain the total difference of milk yield between the 2 groups for the entire period of lactation. The general formula to calculate this difference can be summarized as follows:

$$
\begin{gathered}
\text { difference in MY }= \\
\Sigma \text { wk } 1 \text { to } 14(\text { MYMEL }- \text { MYCONT } \times 7),
\end{gathered}
$$

where MY $=$ milk yield, MEL $=$ melatonin group, and $\mathrm{CONT}=$ control group.

\section{Milk Composition}

At each occasion when milk yield was estimated, a sample of $20 \mathrm{~mL}$ was taken from the hand milking and placed in pre-labeled sterile plastic bags, maintained on ice, and transported to the laboratory. Fat, protein, and lactose percentages in the milk samples were determined with a milk analyzer (Milkoscan 6000, Foss Electric, Hillerød, Denmark).

\section{Plasma T3 Concentrations}

Plasma T3 concentrations in 8 does from each group were determined at 5 and 6 wk after starting the dry period, then, at 2, 6, 10, and $14 \mathrm{wk}$ of lactation. Blood samples were collected from each doe $2 \mathrm{~h}$ after the end of milking (before grazing), via jugular venipuncture, using a sterile syringe and tubes containing sodium heparin $(30 \mu \mathrm{L})$. Immediately after collection, samples were placed on ice and transported to the laboratory. Plasma was harvested by centrifugation at 2,000 $\times \mathrm{g}$ for $30 \mathrm{~min}$ at $4^{\circ} \mathrm{C}$ and stored at $-15^{\circ} \mathrm{C}$ until analysis. Plasma T3 concentrations were determined by ELISA (EIA-4569, DRG Diagnostics, Marburg, Germany) following the manufacturer's protocol. The sensitivity of the essay was $0.60 \mathrm{ng} / \mathrm{mL}$. The intra- and interassay coefficients of variation were 2.64 and $4.66 \%$, respectively.

\section{BW and Mean Daily Weight Gain of the Kids}

In the CONT group goats gave birth to 9 female and 16 male kids, and this ratio was 9 and 8 in the MEL 


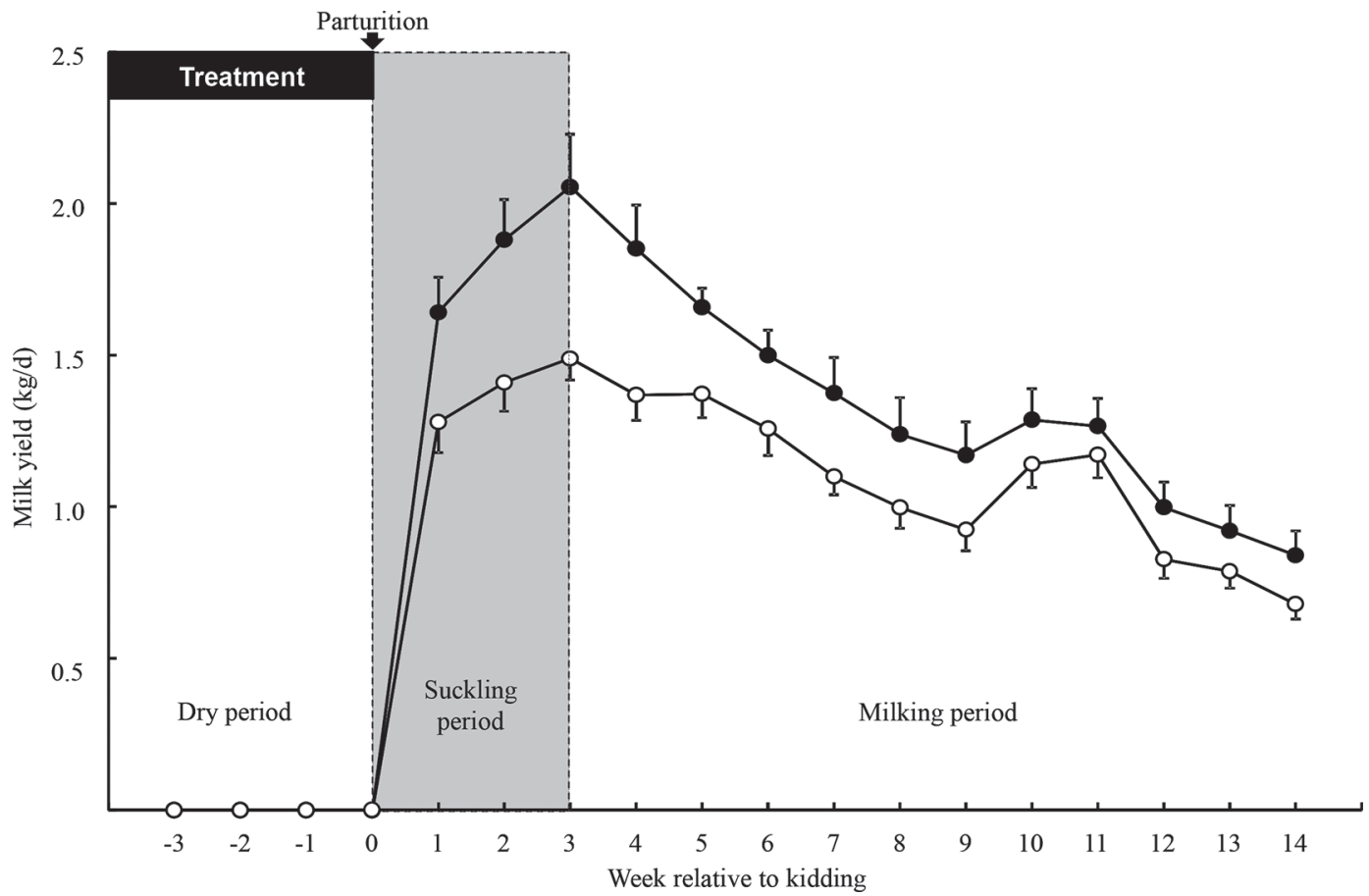

Figure 2. Least squares means $( \pm$ SEM) of milk yield of does during suckling and milking periods. One group of does received the natural long days prevailing during the summer solstice during dry-off (control group; $\mathrm{n}=15 ; \bigcirc$ ), and the second group was managed in the same conditions, but each doe received 2 subcutaneous ear melatonin implants (18 $\mathrm{mg}$ of melatonin; $\mathrm{n}=10 ; \boldsymbol{\bullet})$. A treatment effect was observed for this variable $(P=0.001)$.

group. The kids were weighed at birth and then at 1,2 , and $3 \mathrm{wk}$ using an electronic balance (40 kg capacity) with $0.005 \mathrm{~kg}$ precision and the mean daily weight gain calculated as follows:

(weight at $3 \mathrm{wk}-$ birth weight) $/ 21 \mathrm{~d}$.

\section{Statistical Analyses}

Data from milk yields, milk quality, plasma T3 concentrations and the weight of the kids were analyzed using the LINEAR MIXED MODELS procedure of STATGRAPHICS plus version 5.1 (Statpoint, Herndon, VA). The procedure included the fixed effects of treatment (2 levels: CONT and MEL, the error term being goat within treatment), week of lactation (the residual error being the error term), their interaction, and the random effects of goat and residual. All dependent variables were included as repeated measures. Separate individual independent $t$-tests were also performed to compare point by point milk yields. The relationships between milk yield during the suckling period and the mean daily weight gain of the goat kids were estimated using the Pearson correlation procedure. The level of significance was set at $P<0.05$.

\section{RESULTS}

\section{Milk Yield}

During the suckling period, mean milk yield was greater in MEL than in CONT does (Figure 2, treatment effect $P=0.001$ ). The milk yield during this phase increased in both groups (week effect, $P=0.035$ ). The effect of treatment was maintained during the milking period $(P=0.001)$ during which period milk yield was declining $(P=0.001)$. The calculated difference in total milk yield per doe during all lactation (from wk 1 to 14) for the MEL group was $30.6 \pm 1.6 \mathrm{~kg}$ higher than for the CONT group.

\section{Milk Composition}

During the entire period studied, mean milk contents of fat, protein, and lactose were affected by week of lactation $(P=0.001)$, although no significant effects of treatment were observed (Figure 3 ).

\section{Plasma T3 Concentrations}

Plasma T3 concentrations were similar in both groups at 5 wk after the onset of dry period (Figure 4, 
$P>0.05)$. However, 2 wk before parturition and during lactation, T3 concentrations were greater in MEL than in CONT does (main effect of treatment, $P=0.046$ ).

\section{BW and Mean Daily Weight Gain of Kids}

Age had an effect of on kid weight (week effect, $P=$ 0.001; Figure 5, left). At age of $21 \mathrm{~d}$, the mean BW of the male kids from MEL does was greater than that of female kids from the same group and from goat kids (males and females) from the CONT does. An interaction (treatment $\times$ age) on BW of goat kids was detected $(P<0.001)$. The covariate analysis reveals that the sex of the kids had an effect $(P<0.001)$ on the BW throughout the study. The overall mean daily weight gain was affected by treatment, thus being greater for MEL than CONT goat kids $(P<0.001$, Figure 5 , right $)$.

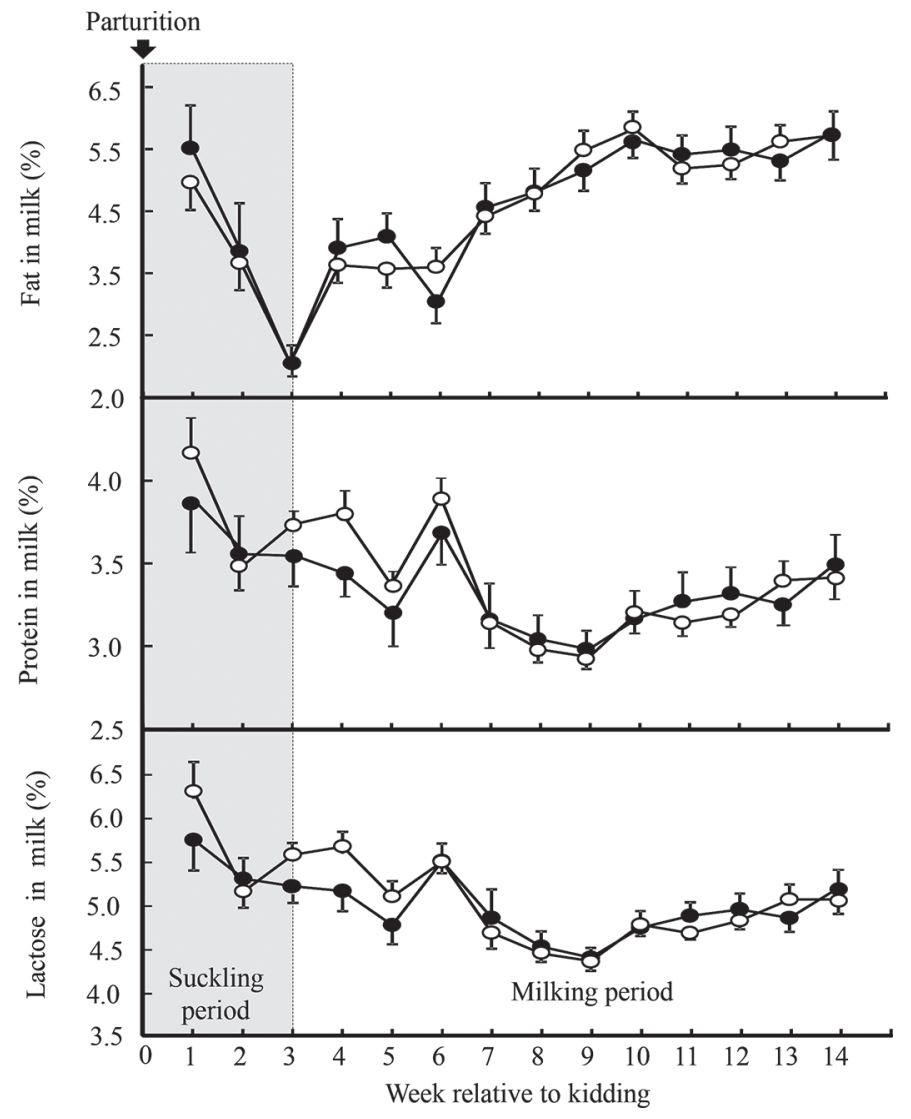

Figure 3. Least squares means $( \pm$ SEM) of percentage contents of fat (upper), protein (middle), and lactose (bottom) in milk from does that received the natural long days prevailing during the summer solstice at dry period (control group; $\bigcirc ; \mathrm{n}=15$ ). The second group was managed in the same conditions, but each doe received 2 subcutaneous ear melatonin implants $(18 \mathrm{mg}$ of melatonin; $\mathbf{0} ; \mathrm{n}=10)$. No differences $(P>0.05)$ were observed in milk constituents between treatments; only milk components were affected by week $(P<0.001$ for each individual milk constituent).

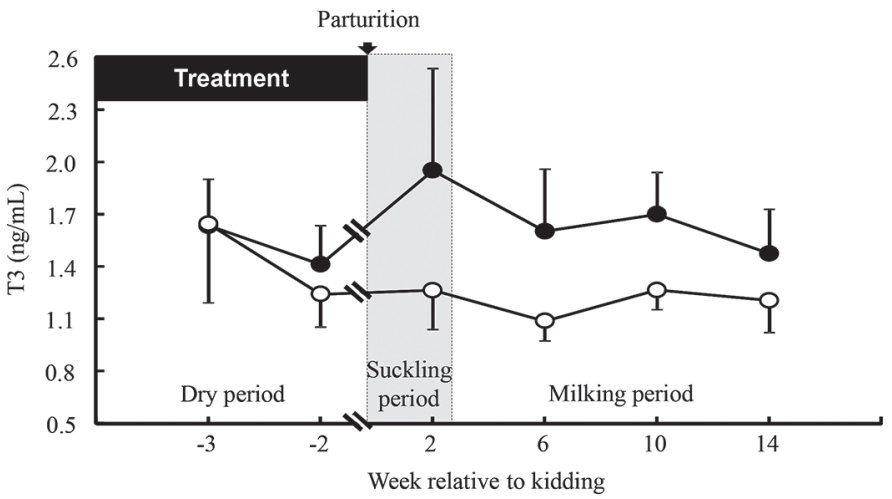

Figure 4. Pattern of LSM in $( \pm \mathrm{SEM})$ plasmatic triiodothyronine (T3) concentrations from goats that received the natural long days prevailing during the summer solstice during the dry period (control group; $\mathrm{n}=15$; $\mathrm{O}$ ). The second group was managed in the same conditions, but each doe received 2 subcutaneous ear melatonin implants (18 mg of melatonin; $\mathrm{n}=10 ; \bullet)$. No differences $(P>0.05)$ were observed in plasma T3 concentrations at any stage of the study, but the effect of treatment was significant $(P=0.04)$.

\section{Correlations Between Dam's Mean Milk Yield and Daily Weight Gain of Kids}

No correlation between dam's mean milk yield over the first 3 wk with the daily weight gain of goat kids was found $(\mathrm{r}=0.2, P>0.05, \mathrm{n}=42)$. However, when considering weight gain of males only, a positive correlation with mean milk yield from their dams was observed $(\mathrm{r}=0.4, P=0.05, \mathrm{n}=24$; Figure 6$)$.

\section{DISCUSSION}

Results obtained in this study agreed with studies in ruminants subjected during the dry period to an artificial short-day photoperiod (Auchtung et al., 2005; Mabjeesh et al., 2007, 2013) and yielded more milk during the subsequent lactation than animals submitted to an artificially long-day photoperiod. Therefore, we hypothesize that our results suggest that melatonin treatment in does did mimic the perception of short days and lead to the stimulatory effect on milk production in the subsequent lactation.

In the present study, this effect was probably observed as the melatonin implants during the dry period could have reduced the PRL levels as in does subject to short-day photoperiods (Mabjeesh et al., 2007). Then, the reduced PRL levels would have stimulated mammary gland involution and resulted in a higher production of milk during the subsequent lactation. The effects of reduced PLR on mammary involution and milk production in the subsequent lactation were previously observed in rats and dairy cows (Travers et al., 1996; Ollier et al., 2013). The exposure of dairy cows 


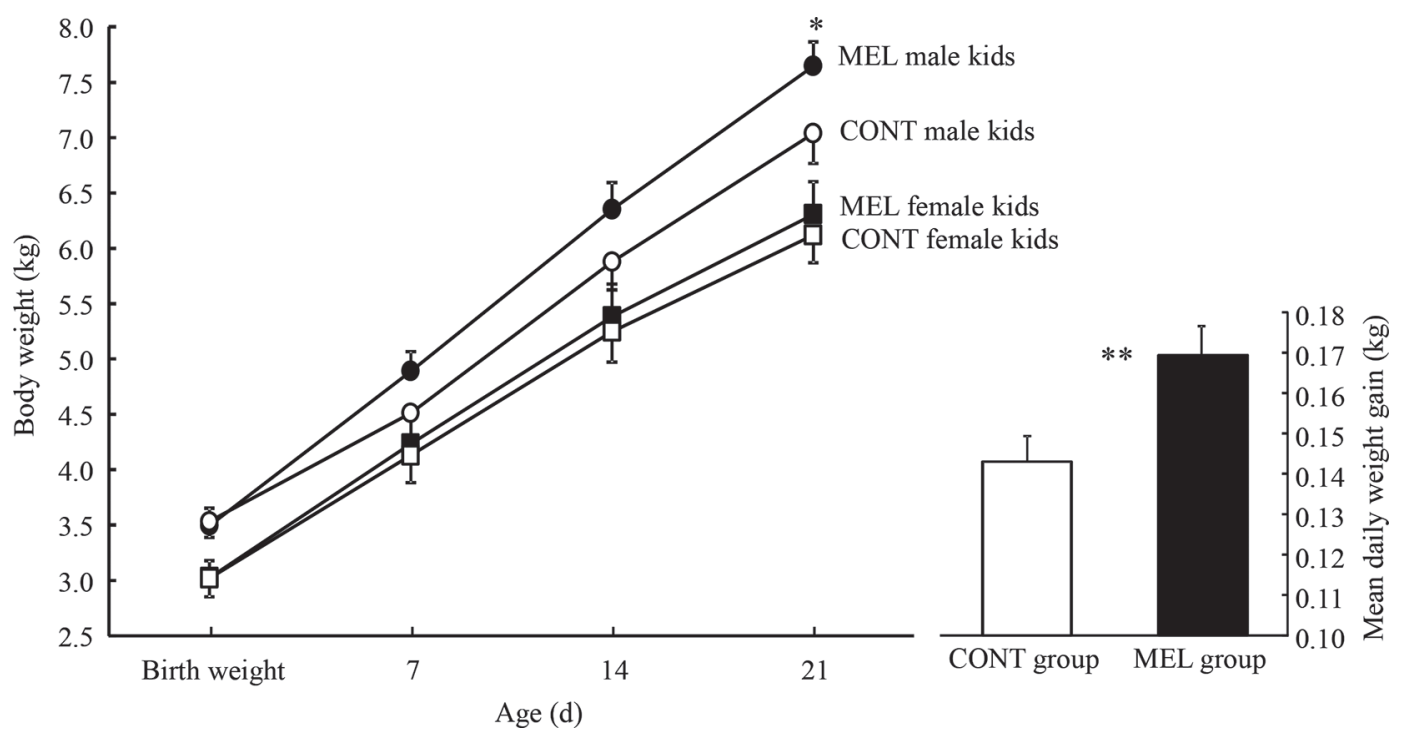

Figure 5. Least squares means ( \pm SEM) of changes in BW of kids (male and females) from does that received the natural long days prevailing during the summer solstice at the dry-off (CONT group; $\mathrm{n}=25$; empty markers). The second group was managed in the same conditions, but each doe received 2 subcutaneous ear melatonin implants (18 $\mathrm{mg}$ of melatonin; MEL group; $\mathrm{n}=17$; full markers). There was a significant effect of time as well as an interaction of time $\times$ group $(P<0.001$ and $P<0.01$, respectively $)$ on BW of the kids. The right panel shows the mean daily weight gain when taking into account all kids from both groups. ${ }^{*} P<0.05 ; * * P<0.01$.

to a short-day photoperiod during the dry period also reduces plasma PRL concentrations, but PRL receptor expression increases in many tissues, including the liver, mammary gland, and lymphocytes (Auchtung et al., 2003, 2005). Thus, the high melatonin levels and low PLR levels may have resulted in enhanced lactogenesis, activating a larger number of mammary secretory cells or increasing their secretory capacity.

Heat stress during the dry period is another environmental factor that could affect the subsequent milk yield in does from our study. The recorded THI indicated that our pregnant does were under heat stress during their dry period. However, both groups of does were under the same heat stress effect. In other ruminant species heat stress has been reported to modify milk yield in the subsequent lactation (Tao et al., 2012; Fabris et al., 2019). In fact, in dairy cattle cooling during the entire dry period results in a higher milk yield and exposure to heat stress at any time during the dry period reduces milk, protein, and lactose yields in the subsequent lactation. Furthermore, heat stress during the dry period reduces the gestation length and calf birth weight. These effects are probably related to a reduction in DMI by the pregnant cow (Fabris et al., 2019). However, Mabjeesh et al. (2013) confirmed that under heat stress conditions during the dry period, goats under a short-day photoperiod produce more milk during subsequent lactation than goats maintained under a long-day photoperiod. It has been proposed that exposure to short-day photoperiod during dry period can be used to as an strategy to reduce the carryover effect of heat stress observed during the subsequent lactation (Mabjeesh et al., 2013).

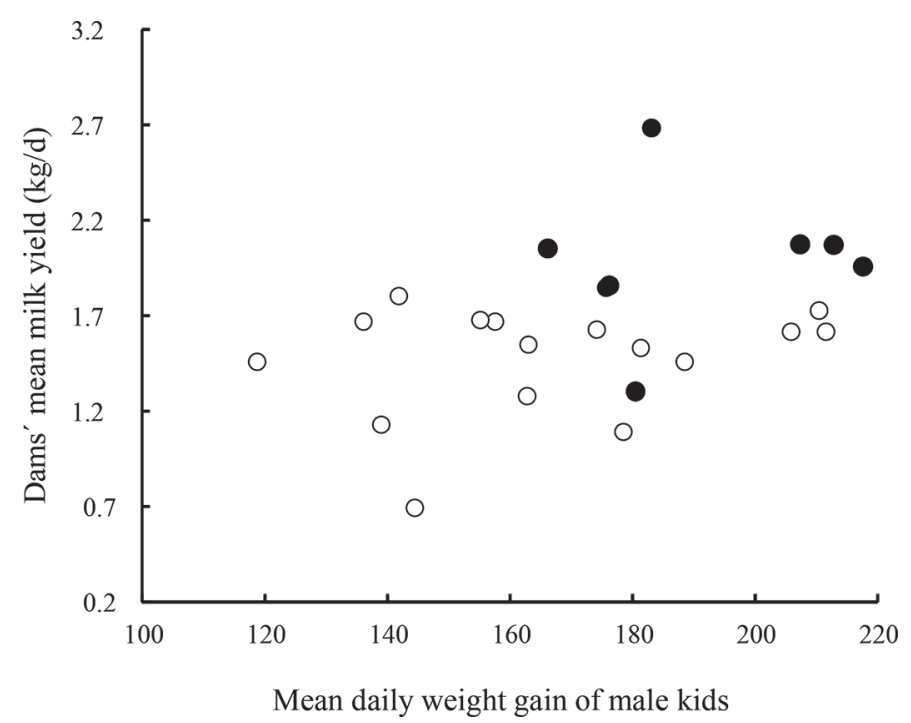

Figure 6. Relationships between mean daily weight gain of male kids and the mean milk yield for their dams exposed to the natural long days during their dry periods prevailing during the summer solstice (control group; $\mathrm{n}=16 ; 0$ ). In the second group of male kids, dams were under in the same conditions during the dry period, but each doe received 2 subcutaneous ear melatonin implants $(18 \mathrm{mg}$ of melatonin; $\mathrm{n}=8 ; \bullet)$. A significant positive correlation $(\mathrm{r}=0.4, P=$ $0.05)$ was observed. 
Results obtained in this study in nursing does disagree with previous studies in dairy cows, where administration of exogenous melatonin during the dry period, either orally or by means of implants, did not affect the milk yield in the subsequent lactation (Garcia-Ispierto et al., 2013; Lacasse et al., 2014; Morini et al., 2018). Several aspects should be considered for this discrepancy. Possible species differences could explain the discordant response. Moreover, the sensitivity to the effect of exogenous melatonin may differ between cows and does. For example, in dairy cows during dry period melatonin implants moderately suppress prepartum PRL concentration but do not affect milk production (Garcia-Ispierto et al., 2013). It is thought that this treatment cannot be used to mimic effects on milk production by exposure to a short-day photoperiod (Lacasse et al., 2014). By contrast, it is well documented that for goats, treatment with exogenous melatonin decreases PRL levels (Prandi et al., 1987; Hashizume et al., 2013), which indicates a high sensitivity to treatment with this hormone. For this reason, in male goats from a local breed, the treatment with artificial long days followed by application of exogenous melatonin induces an intense sexual activity during the natural nonbreeding season (Delgadillo et al., 2001).

In this study, in the lactation following melatonin implant treatment does in their dry period, elevated peripheral T3 levels were recorded. However, this was unlikely due to a direct effect of the melatonin implant on the T3, rather being an indication of the elevated metabolism in these does. The higher metabolic activity was probably required for sustaining the increased milk production. This is similar to increased T3 levels observed in Saanen goats exposed to a short-day photoperiod during the dry period, which also yielded more milk than those exposed to a long-day photoperiod (Mabjeesh et al., 2007). Thyroid hormones play an important role in the metabolic regulation of lactation and therefore are part of the galactopoietic hormone complex (Cowie et al., 1980). In fact, in does, the main effects of T3 are to increase the basal metabolic rate, to make more glucose available to cells, to stimulate protein synthesis, and to increase lipid metabolism (Todini et al., 2007).

The higher milk yield in MEL compared with CONT does resulted in some increase in the daily weight gain of their offspring. Interestingly, the significant increase in weight gain was observed only for male kids. Male kids grow and gain weight faster than female kids (Mavrogenis et al., 1984). This sex effect observed in the present study is parallel to those obtained in a recent study by Flores et al. (2018). These authors observed that treatment with artificial long days to goat kids from d 4 up to $27 \mathrm{~d}$ of age induces a greater daily weight gain in males than in females. Similarly, Pehlivan (2019) found that, only in males and not in female kids, IGF-I concentrations (which are related to their growth) are positively correlated with BW, withers height, rump height, body length, and chest depth. In our study, the positive correlation between mean milk yields of dams with the daily weight gain in male kids (Figure 6) supports previous observation that the BW gain of kids is directly related to the level of their dam's milk yield (García y González et al., 2017).

In this study, the tested milk components (fat, protein, and lactose) did not differ between the 2 groups. The absence of milk composition changes caused by melatonin administration during the dry period is consistent with what was reported in goats and dairy cows that were treated with a short-day photoperiod (Auchtung et al., 2005; Mabjeesh et al., 2007).

Undoubtedly, the use of a short-day photoperiod during dry period could be used as a husbandry procedure to stimulate lactation. In addition, the present results support the role played by the greater time of melatonin secretion on the stimulation of subsequent lactation and, in turn, on the weight gain of their offspring.

\section{CONCLUSIONS}

We concluded that melatonin administration to does during the dry period resulted in a galactopoietic response in the subsequent lactation and that this effect improved the mean daily weight gain of their suckling kids. It is important to emphasize that the objectives of this study were to determine if, in the does, the milk production could be affected by treatment with melatonin during the dry period and the possible effect on the growth of the offspring.

\section{ACKNOWLEDGMENTS}

The authors thank Jesús Abasta for facilitating the use of their flock and farm where the present study was performed. The authors express thanks to Roy Kirkwood (Davis RC, Adelaide, Australia) for his constructive comments of this manuscript. H. Hernández extends infinite thanks to Pascal Poindron (INRA, Tours, France) for his doctoral training and friendship. He also extends his thanks to Dolores López and Esther Peña from UAAAN for the excellent secretarial assistance. The authors also thank Gumaro Treviño, Carmen Avilés, Erick Ramón Guzmán, Andrés Sánchez, Pablo Sifuentes, and Erika Grimaldo from UAAAN for the care of the animals and the technical assistance during the study. R. Avilés was supported by a grant from CONACyT (CDMX, México) during his doctoral studies. This research was conducted as part of the CA- 
BRAA International Associated Laboratory between Mexico (UAAAN-CIRCA) and France (INRA-PRC).

\section{REFERENCES}

Auchtung, T. L., P. E. Kendall, J. L. Salak-Johnson, T. B. McFadden, and G. E. Dahl. 2003. Photoperiod and bromocriptine treatment effects on expression of prolactin receptor mRNA in bovine liver, mammary gland and peripheral blood lymphocytes. J. Endocrinol. 179:347-356.

Auchtung, T. L., A. G. Ruis, P. E. Kendall, T. B. McFadden, and G. E. Dahl. 2005. Effects of photoperiod during the dry period on prolactin, prolactin receptor, and milk production of dairy cows. J. Dairy Sci. 88:121-127.

Auldist, M. J., S.-A. Turner, C. D. McMahon, and C. G. Prosser. 2007. Effects of melatonin on the yield and composition of milk from grazing dairy cows in New Zealand. J. Dairy Res. 74:52-57.

Cowie, A. I., L. A. Forsylth, and I. C. Hart. 1980. Control of Lactation. Springer-Verlag, Berlin, Germany.

Cowie, A. T., G. S. Knaggs, and J. S. Tindal. 1964. Complete restoration of lactation in the goat after hypophysectomy. J. Endocrinol. 28:267-279.

Dahl, G. E., B. A. Buchanan, and H. A. Tucker. 2000. Photoperiodic effects on dairy cattle: A review. J. Dairy Sci. 83:885-893.

Delgadillo, J. A., E. Carrillo, J. Morán, G. Duarte, P. Chemineau, and B. Malpaux. 2001. Induction of sexual activity of male Creole goats in subtropical northern Mexico using long days and melatonin. J. Anim. Sci. 79:2245-2252.

Deveson, S. L., J. Howarth, J. Arendt, and I. A. Forsyth. 1990. Sensibility of goats to a light pulse during the night as assessed by suppression of melatonin concentration in plasma. J. Pineal Res. 8:169-177.

Duarte, G., M. P. Nava-Hernández, B. Malpaux, and J. A. Delgadillo. 2010. Ovulatory activity of female goats adapted to the subtropics is responsive to photoperiod. Anim. Reprod. Sci. 120:65-70.

Fabris, T. F., J. Laporta, A. L. Skibiel, F. N. Corra, B. D. Senn, S. E. Wohlgemuth, and G. E. Dahl. 2019. Effect of heat stress during early, late, and entire dry period on dairy cattle. J. Dairy Sci. 102:5647-5656.

Flores, M. J., J. A. Flores, G. Duarte, J. Vielma, J. A. Delgadillo, and H. Hernández. 2018. Artificial long-day photoperiod in the subtropics increases body weight in goat kids born in the autumn. Small Rumin. Res. 169:181-185.

Flores, M. J., J. A. Flores, J. M. Elizundia, A. Mejía, J. A. Delgadillo, and H. Hernández. 2011. Artificial long-day photoperiod in the subtropics increases milk production in goats giving birth in late autumn. J. Anim. Sci. 89:856-862.

Garcia-Ispierto, I., A. Abdelfatah, and F. López-Gatius. 2013. Melatonin treatment at dry-off improves reproductive performance postpartum in high-producing dairy cows under heat stress conditions. Reprod. Domest. Anim. 48:577-583.

García y González, E., J. A. Flores, J. A. Delgadillo, T. GonzálezQuirino, I. G. Fernández, A. Terrazas, J. Vielma, E. Nandayapa, E. S. Mendieta, J. Loya-Carrera, M. J. Flores, and H. Hernández. 2017. Early nursing behaviour in ungulate mothers with hider offspring (Capra hircus): Correlations between milk yield and kid weight. Small Rumin. Res. 151:59-65.

Hashizume, T., T. Yaegashi, J. Jin, K. Sawai, F. Fülöp, and G. M. Nagy. 2013. Effects of melatonin on salsolinol-induced prolactin secretion in goats. Anim. Sci. J. 84:334-340.

Lacasse, P., C. M. Vinet, and D. Petitclerc. 2014. Effect of prepartum photoperiod and melatonin feeding on production and prolactin concentration in dairy heifers and cows. J. Dairy Sci. 97:3589-3598.

Linzell, J. L. 1973. Innate seasonal oscillations in the rate of milk secretion in goat. J. Physiol. 230:225-233.
Mabjeesh, S. J., O. Gal-Garber, and A. Shamay. 2007. Effect of photoperiod in the third trimester of gestation on milk production and circulating hormones in dairy goats. J. Dairy Sci. 90:699-705.

Mabjeesh, S. J., C. Sabastian, O. Gal-Gerber, and A. Shamay. 2013. Effect of photoperiod and heat stressing the third trimester of gestation on milk production and circulating hormones in dairy goats. J. Dairy Sci. 96:189-197.

Mavrogenis, A. P., A. Constantinou, and A. Louca. 1984. Environmental and genetic causes of variation in production traits of Damascus goats. 1. Pre-weaning and post-weaning growth. Anim. Prod. 38:91-97.

Morini, G., M. Pittella, A. Poli, and F. De Rensis. 2018. Effect of melatonin administration prior to calving on milk secretion in the next lactation in dairy cows. Vet. Stanica. 2:85-89.

Ollier, S., X. Zhao, and P. Lacasse. 2013. Effect of prolactin-release inhibition on milk production and mammary gland involution at drying-off in cows. J. Dairy Sci. 96:335-343.

Ortavant, R., F. Bocquier, J. Pelletier, J. P. Ravault, J. Thimonier, and P. Volland-Nail. 1988. Seasonality of reproduction in sheep and its control by photoperiod. Aust. J. Biol. Sci. 41:69-85.

Pehlivan, E. 2019. Relationship between insulin-like growth factor-1 (IGF-1) concentrations and body trait measurements and climatic factors in prepubertal goat kids. Arch. Tierzucht 62:241-248.

Peters, R. R., L. T. Chapin, R. S. Emery, and H. A. Tucker. 1981. Milk yield, feed intake, prolactin, growth hormone, and glucocorticoid response of cows to supplemented light. J. Dairy Sci. 64:1671-1678.

Ponchon, B., P. Lacasse, S. Ollier, and X. Zhao. 2017. Effects of photoperiod modulation and melatonin feeding around drying-off on bovine mammary gland involution. J. Dairy Sci. 100:8496-8506.

Prandi, A., G. Romagnoli, F. Chiesa, and C. Tamanini. 1987. Plasma prolactin variations and onset of ovarian activity in lactating anestrous goats given melatonin. Anim. Reprod. Sci. 13:291-297.

Ricordeau, G., R. Boccard, and R. Denamur. 1960. Mesure de la production laitière des brebis pendant la période d'allaitement. Ann. Zootech. 9:97-120.

SAGARPA. 2001. Secretaría de Agricultura, Ganadería, Desarrollo Rural, Pesca y Alimentación. Norma Oficial Mexicana NOM-062ZOO-1999, Especificaciones técnicas para la producción, cuidado y uso de los animales de laboratorio. Diario Oficial de la Federación. June 18, 2001.

SIAP (Sistema de información agropecuaria y pesquera). 2014 SAGARPA: Secretaría de agricultura, ganadería desarrollo rural pesca y alimentación. Accessed Dec. 5, 2017. http://www.siap.gob $. \mathrm{mx} / \mathrm{opt} /$ poblagand/caprino.pdf.

Tao, S., A. P. A. Monteiro, I. M. Thompson, M. J. Hayen, and G. E. Dahl. 2012. Effect of late-gestation maternal heat stress on growth and immune function of dairy calves. J. Dairy Sci. 95:7128-7136.

Todini, L., A. Malfatti, A. Valbonesi, M. Trabalza-Marinucci, and A. Debenedetti. 2007. Plasma total T3 and T4 concentrations in goats at different physiological stages, as affected by the energy intake. Small Rumin. Res. 68:285-290.

Travers, M. T., M. C. Barber, E. Tonner, L. Quarrie, C. J. Wilde, and D. J. Flint. 1996. The role of prolactin and growth hormone in the regulation of casein gene expression and mammary cell survival: Relationships to milk synthesis and secretion. Endocrinology 137:1530-1539.

Wall, E. H., T. L. Auchtung-Montgomery, G. E. Dahl, and T. B. McFadden. 2005. Short-Day photoperiod during the dry period decreases expression of suppressors of cytokine signaling in mammary gland of dairy cows. J. Dairy Sci. 88:3145-3148.

\section{ORCIDS}

H. Hernández @ https://orcid.org/0000-0002-0569-8888 